\title{
Assessment of the Energy Impacts of Improving Highway-Infrastructure Materials
}

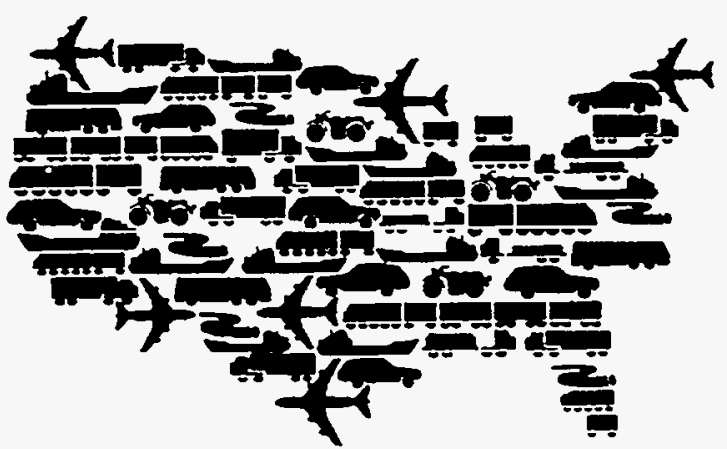

Center for Transportation Research Argonne National Laboratory

Operated by The University of Chicago, under Contract W-31-109-Eng-38, for the United States Department of Energy 


\section{Argonne National Laboratory}

Argonne National Laboratory, with facilities in the states of Illinois and Idaho, is owned by the United States Government, and operated by the University of Chicago under the provisions of a contract with the Department of Energy.

This technical memo is a product of Argonne's Energy Systems (ES) Division. For information on the division's scientific and engineering activities, contact:

$$
\begin{aligned}
& \text { Director, Energy Systems Division } \\
& \text { Argonne National Laboratory } \\
& \text { Argonne, Illinois 60439-4815 } \\
& \text { Telephone (708) 252-3724 }
\end{aligned}
$$

Presented in this technical memo are preliminary results of ongoing work or work that is more limited in scope and depth than that described in formal reports issued by the ES Division.

Publishing support services were provided by Argonne's Information and Publishing Division (for more information, see IPD's home page: http://www.ipd.anl.gov/).

\section{Disclaimer}

This report was prepared as an account of work sponsored by an agency of the United States Government. Neither the United States Government nor any agency thereof, nor any of their employees, makes any warranty, express or implied, or assumes any legal liability or responsibility for the accuracy, completeness, or usefulness of any information, apparatus, product, or process disclosed, or represents that its use would not infringe privately owned rights. Reference herein to any specific commercial product, process, or service by trade name, trademark, manufacturer, or otherwise, does not necessarily constitute or imply its endorsement, recommendation, or favoring by the United States Govemment or any agency thereof. The views and opinions of authors expressed herein do not necessarily state or reflect those of the United States Govemment or any agency thereof.

Reproduced directly from the best available copy.

Available to DOE and DOE contractors from the Office of Scientific and Technical Information, P.O. Box 62, Oak Ridge, TN 37831 ; prices available from (423) 576-8401.

Available to the public from the National Technical Information Service, U.S. Department of Commerce, 5285 Port Royal Road, Springfield, VA 22161. 


\section{Assessment of the Energy Impacts of Improving Highway-Infrastructure Materials}

R.E. Stammer Jr.* and F. Stodolsky

Center for Transportation Research, Energy Systems Division, Argonne National Laboratory, 9700 South Cass Avenue, Argonne, Illinois 60439

April 1995

Work sponsored by United States Department of Energy, Assistant Secretary for Energy Efficiency and Renewable Energy, Office of Transportation Materials

"Stammer is affiliated with the School of Engineering, Vanderbilt University, Nashville, Tennessee. 
This report is printed on recycled paper. 


\section{CONTENTS}

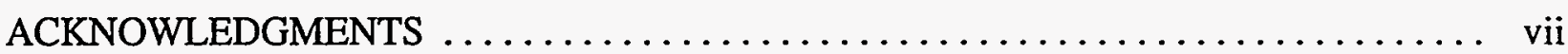

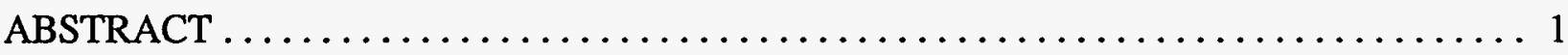

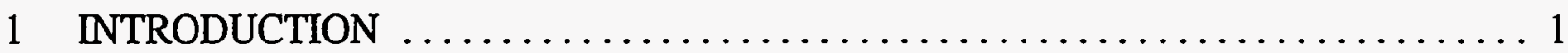

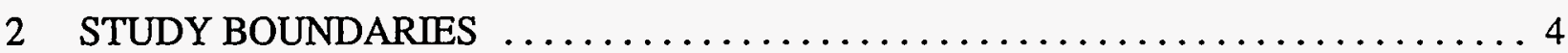

3 CURRENT MATERIALS AND ENERGY CONSUMPTION STATISTICS $\ldots \ldots \ldots \ldots 5$

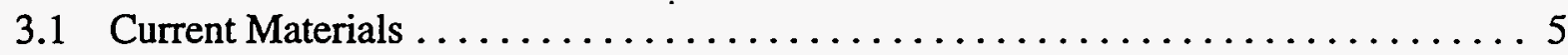

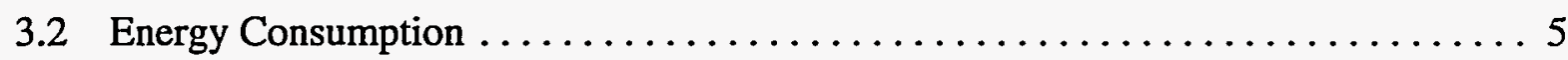

4 HIGHWAY-INFRASTRUCTURE INVENTORY $\ldots \ldots \ldots \ldots \ldots \ldots \ldots$

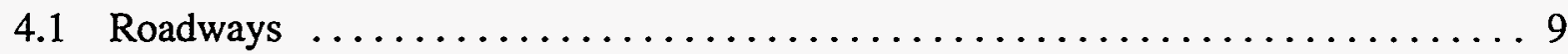

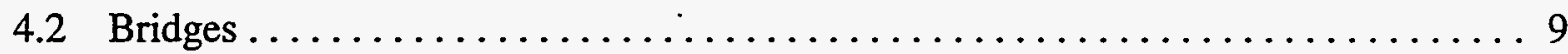

5 INFRASTRUCTURE LIFE EXPECTANCY AND TRAFFIC-TIME-

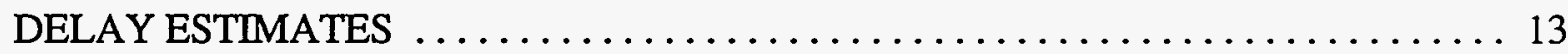

5.1 Review of Current Roadway and Bridge Ages . . . . . . . . . . . . . 13

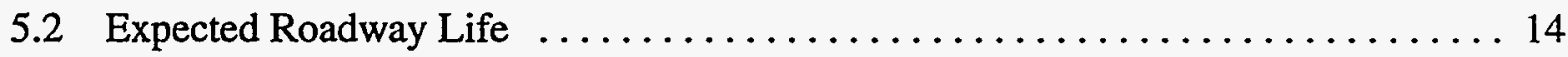

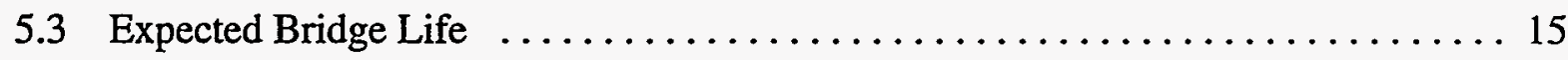

5.4 Construction and Maintenance Time-Period Requirements $\ldots \ldots \ldots \ldots \ldots \ldots \ldots$

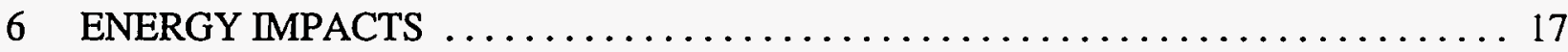

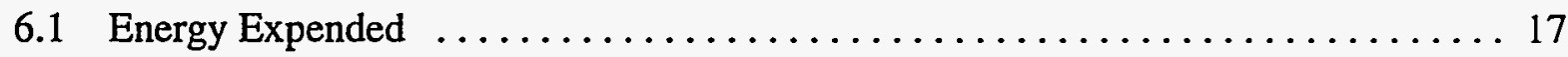

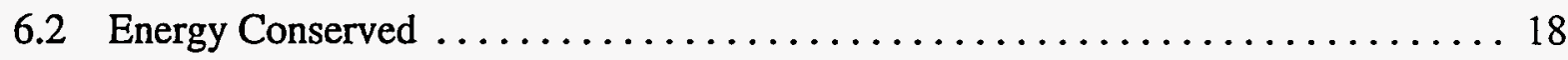

6.3 Overview of Possible Strategies $\ldots \ldots \ldots \ldots \ldots \ldots \ldots \ldots \ldots \ldots \ldots \ldots \ldots \ldots \ldots \ldots \ldots \ldots$

7 DEVELOPMENT OF A PROCESS FOR EVALUATION OF ENERGY

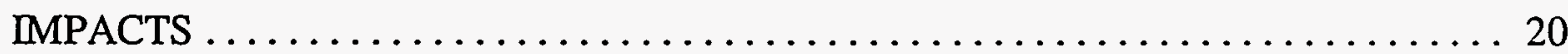

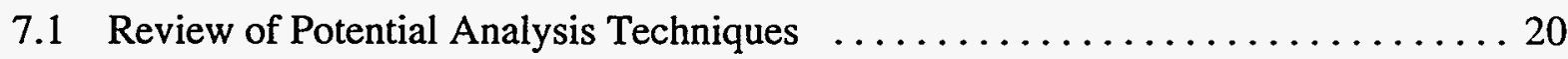

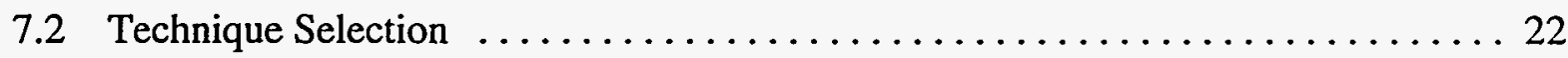




\section{CONTENTS (Cont.)}

8.1 Scenario 1: Change in Rolling Resistance Coefficient $\ldots \ldots \ldots \ldots \ldots \ldots \ldots 24$

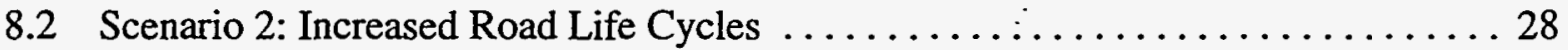

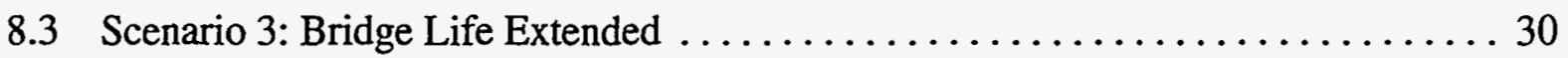

8.4 Scenario 4: Less Road Maintenance Required ................... 32

8.5 Scenario 5: Less Bridge Maintenance Required ................... 36

8.6 Scenario 6: Reduced Volume of Road Materials Required $\ldots \ldots \ldots \ldots \ldots \ldots 40$

8.7 Scenario 7: Stronger, Smaller Bridges are Developed $\ldots \ldots \ldots \ldots \ldots \ldots \ldots 43$

8.8 Scenario 8: Vehicular Traffic Congestion Reduced .................. 45

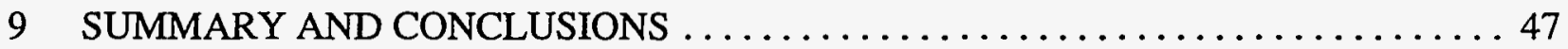

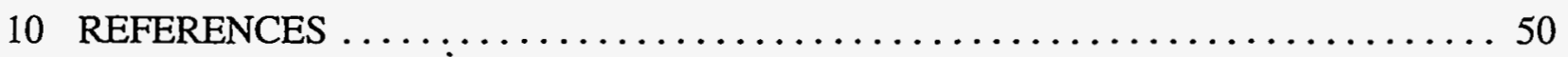

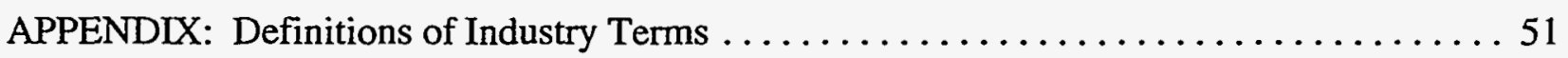

TABLES

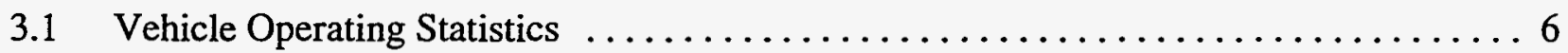

3.2 Energy Requirements for Construction Materials $\ldots \ldots \ldots \ldots \ldots \ldots \ldots \ldots \ldots$

3.3 Facility Maintenance Statistics $\ldots \ldots \ldots \ldots \ldots \ldots \ldots \ldots \ldots \ldots \ldots \ldots$

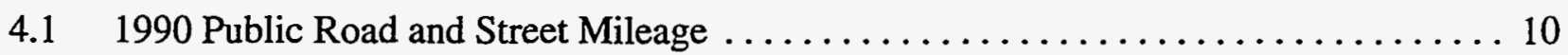

4.2 Estimated Cost of Replacing or Rehabilitating Currently Deficient Bridges Eligible for the Highway Bridge Replacement and Rehabilitation Program, Including Federal and State Shares $\ldots \ldots \ldots \ldots \ldots \ldots \ldots \ldots \ldots \ldots \ldots \ldots$

4.3 Estimated Investment Requirements by All Units of Government to Eliminate All Existing and Accruing Federal-Aid-System Bridge Deficiencies, 1987-2005 . . . . 12 


\section{TABLES (Cont.)}

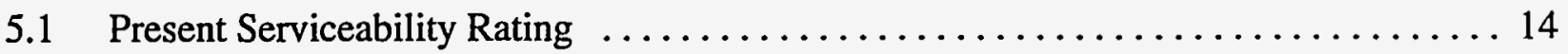

5.2 Estimated Construction and Maintenance Time Periods and Traffic Delays $\ldots \ldots \ldots 16$

8.1 Rolling Resistance Energy Savings, $5 \% \mathrm{f}_{\mathrm{R}}$ Reduction $\ldots \ldots \ldots \ldots \ldots \ldots \ldots \ldots \ldots \ldots \ldots$

8.2 Rolling Resistance Energy Savings, $10 \% \mathrm{f}_{\mathrm{R}}$ Reduction $\ldots \ldots \ldots \ldots \ldots \ldots \ldots$

8.3 Rolling Resistance Energy Savings, $15 \% \mathrm{f}_{\mathrm{R}}$ Reduction $\ldots \ldots \ldots \ldots \ldots \ldots \ldots \ldots$

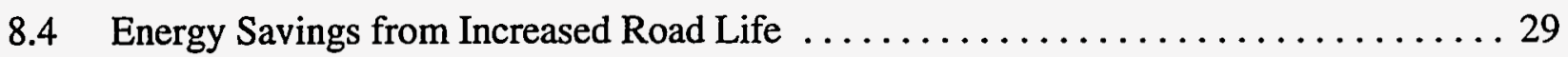

8.5 Energy Savings from Increased Bridge Life $\ldots \ldots \ldots \ldots \ldots \ldots \ldots \ldots \ldots \ldots \ldots \ldots \ldots$

8.6 Energy Savings from Less-Frequently-Required Road Maintenance,

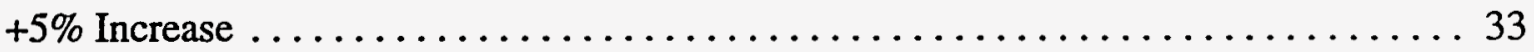

8.7 Energy Savings from Less-Frequently-Required Road Maintenance,

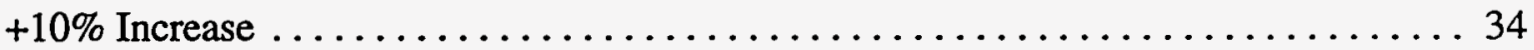

8.8 Energy Savings from Less-Frequently-Required Road Maintenance, $+15 \%$ Increase . . . . . . . . . . . . . . . . . . . . . . . . . . . . 35

8.9 Energy Savings from Less-Frequently-Required Bridge Maintenance,

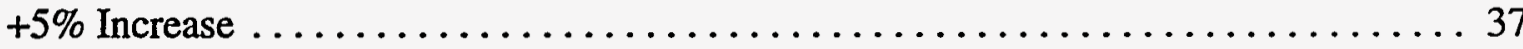

8.10 Energy Savings from Less-Frequently-Required Bridge Maintenance, $+10 \%$ Increase

8.11 Energy Savings from Less-Frequently-Required Bridge Maintenance, $+15 \%$ Increase

8.12 Energy Savings for Roadway-Materials Reduction $\ldots \ldots \ldots \ldots \ldots \ldots \ldots \ldots \ldots$

8.13 Annual Energy Savings Associated with Reductions in Roadway Materials . . . . . . . 42 


\section{TABLES (Cont.)}

8.14 Annual Energy Savings Associated with Reductions in Bridge Materials ... . . . . . 44

8.15 Energy Savings for Reduced Traffic Congestion Associated with Less-Frequent

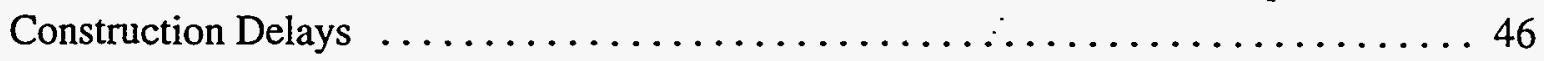

9.1 Summary of Average Annual Energy Savings by Scenario $\ldots \ldots \ldots \ldots \ldots \ldots$ 


\section{ACKNOWLEDGMENTS}

The authors thank James Eberhardt, Office of Transportation Materials, U.S. Department of Energy, for his support and valuable guidance. We also thank Kenneth Opiela of the Transportation Research Board and Roger Wayson of the University of Central Florida for review of an earlier version of this report. In addition, we gratefully acknowledge the editorial services of Ellen Hathaway and Floyd Bennett, Technical Communication Services, and the assistance of the Document Processing and Control Center, Information and Publishing Division, Argonne National Laboratory. 


\title{
ASSESSMENT OF THE ENERGY IMPACTS OF IMPROVING HIGHWAY-INFRASTRUCTURE MATERIALS
}

by

\author{
R.E. Stammer Jr. and F. Stodolsky
}

\begin{abstract}
Argonne National Laboratory has conducted a study to ascertain the relative importance of improved highway materials compared to vehicle energy consumption on U.S. energy consumption. Energy savings through an improved highway infrastructure can occur in at least three ways. First, replacing aged and failing materials with improved and advanced materials can produce energy "use" savings. Second, advances in materials science can yield energy efficiency gains in the production of infrastructure materials. Third, using new or improved transportation-infrastructure materials that have longer service life reduces the energy expended in producing replacement materials and installing or repairing facilities. The Argonne study finds that energy savings from highway materials improvements are on the order of $0.1 \times 10^{12}$ to $2.1 \times 10^{12} \mathrm{Btu}$. This savings is relatively small compared with energy savings from improvements in vehicle fuel economy. Several infrastructure improvement scenarios were examined, with results that were highly dependent on the assumptions. Reducing traffic congestion, particularly in high-traffic-volume locations, produces major energy savings compared with the other scenarios.
\end{abstract}

\section{INTRODUCTION}

The transportation-infrastructure crisis in the United States can be described as the nation's third deficit, the other two being the budget and trade deficits. We find ourselves at a crossroads, and the decisions we make now will affect us for the next several decades. If the United States is to retain its economic preeminence in the twenty-first century, a dramatic reversal must take place in the way we view transportation-infrastructure investment. Our aging highways, air transport system, and railways are showing the signs of more than three decades of neglect. Today's transportation systems are often overtaxed, underfunded, and in need of fundamental modernization. 
Some observers have called the state of our transportation system a major force behind the relative decline in U.S. productivity. The nation's businesses spend more than $\$ 310$ billion per year on moving materials and products through a system in which $70 \%$ of urban travel on interstate highways is subject to congested conditions. That congestion alone costs the nation more than $\$ 34$ billion annually in productive time lost due to delays (National Research Council 1992).

In industry today, efficient transportation is a necessity; for the integrated enterprise of tomorrow, it will be vital. Exacting schedules mandated by just-in-time production and time-tomarket demands make manufacturing logistics an increasingly critical element in the competitive equation for the twenty-first century. The challenge is to create seamless and swift intermodal systems that not only reclaim lost productivity but also contribute value to American industry's competitiveness in an environmentally clean and energy-efficient manner (National Research Council 1992).

Improved energy efficiency, when related to transportation, is an important aspect of our nation's overall energy picture. The transportation sector accounts for about $24 \%$ of all energy consumed in the United States and almost $70 \%$ of the petroleum consumed (Energy Information Administration 1994). In 1992, light-duty vehicles and freight trucks alone accounted for over $80 \%$ of the 22.4 quadrillion $\left(10^{15}\right)$ Btu of energy consumed annually by the transporation sector. Clearly, improvements in energy efficiency in the light-duty and freight truck sectors would greatly affect petroleum consumption. The U.S. Department of Energy (DOE) focuses on research and development of vehicle technologies (engines, materials, and fuels) to improve ground transportation efficiency. DOE's Office of Transportation Materials (OTM) is interested in the potential energy savings due to improved highway materials. Although highway infrastructure is an important component of the overall transportation sector from productivity and cost perspectives, information is scarce on the impact of improved highways on energy consumption. Argonne National Laboratory (ANL) conducted a study in 1992 to ascertain the relative importance of improved highway materials compared to vehicle energy consumption on U.S. energy consumption

Energy savings through an improved highway infrastructure can typically occur in at least three different ways. First, improved and advanced materials used to replace aged and failing materials can produce energy "use" savings. For example, "smoother" roadway surfaces require less vehicle energy when they are traversed. Thus, energy savings may be obtained in the use of an improved infrastructure.

A second type of energy efficiency can be realized in the production of infrastructure materials. New advances in materials science research should reflect the importance of improving the efficiency with which energy is used in producing these new materials. The older, less energyefficient machines, such as the grinders, crushers, heaters, furnaces, and other machinery used in the materials production process, should be replaced. An increased awareness of the magnitude of these energy savings is necessary. 
A third source of energy savings will occur in terms of life-cycle energy savings. If a new, improved, transportation-infrastructure material has a longer service life, less energy will be expended over the life of a facility to produce replacement materials or to install or repair facilities, and additional energy inefficiencies associated with congestion and delays for repairs will be prevented.

Cost barriers can hinder, and even prohibit, the introduction of energy-saving measures within the highway-infrastructure environment. Many existing and readily available highwayinfrastructure materials are far superior to the standard materials that are used at present. However, the higher costs associated with these superior materials represent a formidable barrier to their immediate widespread use. 


\section{STUDY BOUNDARIES}

The energy analysis in this.study is restricted to the highway infrastructure. However, the total transportation infrastructure is very diverse; possible energy savings accrued in the highway arena could result in energy savings in other ground-based transportation modes, such as masstransit systems.

Use, production, and life-cycle energy savings (as defined in the Introduction) are the only three areas studied in detail for this highway-infrastructure materials analysis. Energy expenditures for highway and bridge "placement" (construction) are somewhat speculative and should be considered only if the materials themselves are improved. The amount of energy required to construct roads and bridges is highly variable by facility. This variability presents no major obstacle, however, if one assumes that new-technology materials will be roughly equivalent in size and weight to their predecessors and that construction and placement techniques will remain basically unchanged. Thus, it appears reasonable to assume that the construction techniques and equipment used are largely independent of new and improved materials. Therefore, the placement or construction energy requirements will not be major variables for consideration or detailed analysis.

The fact that costs (whether they be initial, repair, or total life-cycle costs) are the dominant factors in highway-infrastructure-materials decisions must be recognized. Neither energy nor aesthetic issues, nor even safety issues, influence final highway-infrastructure decisions as much as costs do. This fact does not diminish the importance of energy conservation. It indicates that energy savings are often a secondary result (or consideration), rather than the dominant factor in fundamental construction decisions. 


\section{CURRENT MATERIALS AND ENERGY CONSUMPTION STATISTICS}

\subsection{CURRENT MATERIALS}

For most new highway projects, asphalt cement concrete (ACC) tends to be used more often than Portland cement concrete (PCC). (The Appendix contains definitions of terms used by the industry.) Lower initial costs, ease of application, and adaptability to staged construction with little or no waiting by vehicles are reasons for the increased popularity of ACC. However, comparable specifications allowing either PCC or ACC alternatives are becoming more prevalent, so that road contractors can bid either type. This choice gives PCC contractors more opportunities for work and increases their competitiveness. Composite materials offering the most advantageous properties of both techniques are also being developed and used.

One has only to drive the nation's interstates and other highways to realize that most resurfacing is being done with ACC. Even PCC-original pavements are being overlaid or resurfaced with ACC. Recent advancements in PCC overlays are allowing them to be more competitive in certain situations, such as in bridge deck overlays and cold weather applications. Advances in admixtures are the reasons for this increased competitiveness.

In the area of bridges, steel bridges are not the norm. Reinforced concrete (in many different forms) is the bridge construction material of choice. Concrete is corrosion-resistant and can be more easily handled and formed to comply with different design dimensions. Reinforcedconcrete properties can also be more easily modified for different in-place environments. Although concrete is corrosion-resistant, rebar corrosion is a major problem. A technique using cathodic protection $(\mathrm{CP})$ is being tried to combat this problem.

\subsection{ENERGY CONSUMPTION}

Energy is consumed through (1) use of a road or bridge by vehicle traffic, (2) production of component construction materials, (3) actual road or bridge construction, and (4) repairs made over the life of a road or bridge (i.e., during new materials production, additional construction or materials installation, and increased traffic delays).

Step 3 (actual road or bridge construction), along with possible construction technology changes, will not be analyzed in great detail because energy required during construction is a necessary step in every construction cycle and appears to be relatively insensitive to or independent of new developments in construction materials. Some energy-use differences may occur as new materials evolve, but the magnitude of change in relation to energy demands and the forecasting of 
technological advancements associated with construction equipment refinements are beyond the scope of this study.

Table 3.1 presents vehicle operating statistics that will be useful in later, quantitative highway-infrastructure use calculations. Energy requirements for construction materials and in-place energy consumption values are presented in Table 3.2, and Table 3.3 presents facility maintenance statistics. Tables 3.2 and 3.3 will also be beneficial in subsequent energy analyses.

TABLE 3.1 Vehicle Operating Statistics

\begin{tabular}{lccc}
\hline & \multicolumn{2}{c}{ Registrations } & \\
\cline { 2 - 3 } Vehicle Type & Number $^{\mathrm{a}}$ & $\begin{array}{c}\text { Percent by } \\
\text { Type }\end{array}$ & $\begin{array}{c}\text { Average Energy } \\
\text { Consumption } \\
\text { (mi/gal) }\end{array}$ \\
\hline Passenger cars & $143,549,627$ & 76.1 & 19.95 \\
Trucks & $44,478,848$ & 23.6 & 10.17 \\
Buses & 626,987 & 0.3 & 5.94 \\
\hline
\end{tabular}

Annual Vehicle Miles of Travel $(\mathrm{VMT})^{\mathrm{a}}\left(10^{6} \mathrm{mi}\right)$

\begin{tabular}{lrrr} 
Vehicle Type & Urban $^{\mathrm{c}, \mathrm{d}}$ & Rural $^{\mathrm{c}}$ & \multicolumn{1}{c}{ Total } \\
\hline & & & \\
Passenger cars & 958,588 & 566,354 & $1,524,942$ \\
Trucks & 316,229 & 300,602 & 616,831 \\
Buses & 2,275 & 3,453 & 5,728 \\
\hline
\end{tabular}

a Source: Federal Highway Administration (1990).

b Source: Bureau of the Census (1991).

c Representative operating speed for urban/suburban and rural driving is $35 \mathrm{mi} / \mathrm{h}$.

d Includes travel in suburban areas with 5,000+ population. 
TABLE 3.2 Energy Requirements for Construction Materials

\begin{tabular}{lc}
\hline Construction Material & $\begin{array}{c}\text { Energy Utilization } \\
\text { (Btu/ton) }\end{array}$ \\
\hline Initial materials & $:$ \\
Asphalt cement & 600,000 \\
Portland cement & $6,300,000$ \\
Steel (tiebars and rebar) & $21,000,000-24,000,000$ \\
Steel beam & $17,700,000^{\mathbf{b}}$ \\
Aggregate (crushed rock) & 70,000 \\
& \\
Secondary materials & \\
Crushed rock base & $218,000-236,000$ \\
Asphalt cement concrete & $512,000-533,000$ \\
Portland cement concrete & \\
Jointed nonreinforced & $990,000-1,210,000$ \\
Jointed reinforced & $1,390,000$ \\
Continuously & $1,620,000$ \\
reinforced
\end{tabular}

a Energy associated with materials production.

b Data from Charles River Associates, Inc. (1989).

c Includes energy associated with production or manufacturing, mixing, hauling, placing, and compacting.

Source: Epps and Finn (1980). 
TABLE 3.3 Facility Maintenance Statistics ${ }^{\mathrm{a}}$

\begin{tabular}{|c|c|c|c|c|}
\hline \multirow{2}{*}{$\begin{array}{l}\text { Item } \\
\text { No. }\end{array}$} & \multirow{2}{*}{$\begin{array}{c}\text { Type of } \\
\text { Improvement }\end{array}$} & \multicolumn{2}{|c|}{ Number of Miles } & \multirow{2}{*}{$\begin{array}{c}\text { Construction Energy Consumed } \\
\text { per Rural-Lane-Mile }{ }^{\mathrm{b}} \\
\left(10^{9} \mathrm{Btu} / \mathrm{mi}\right)\end{array}$} \\
\hline & & Rural & Urban & \\
\hline 1 & New construction & 204.5 & 167.5 & 12.7 \\
\hline 2 & Relocation & 132.0 & 34.5 & 10.5 \\
\hline 3 & Reconstruction & $1,953.2$ & 605.5 & 5.2 \\
\hline 4 & Restoration and rehabilitation & $1,638.2$ & 414.3 & 2.3 \\
\hline 5 & Resurfacing & $4,206.7$ & 783.8 & 0.75 \\
\hline 6 & Major widening & 304.3 & 225.2 & 5.0 \\
\hline 7 & Minor widening & 700.0 & 114.2 & 1.9 \\
\hline \multirow[b]{2}{*}{$\begin{array}{l}\text { Item } \\
\text { No. }\end{array}$} & \multirow[b]{2}{*}{$\begin{array}{c}\text { Type of } \\
\text { Improvement }\end{array}$} & \multicolumn{2}{|c|}{ Number of Miles } & \multirow{2}{*}{$\begin{array}{c}\text { Construction Energy Consumed } \\
\text { per Rural-Lane-Mile }{ }^{b} \\
\left(10^{9} \mathrm{Btu} / \mathrm{mi}\right)\end{array}$} \\
\hline & & Rural & Urban & \\
\hline 8 & New bridges & 295 & 520 & $192[1.46]^{\mathrm{c}}$ \\
\hline 9 & Bridge replacement & 2,086 & 553 & $222[1.69]$ \\
\hline 10 & Major rehabilitation & 513 & 457 & $134.4[1.02]$ \\
\hline 11 & Minor rehabilitation & 332 & 236 & $11.91[0.09]$ \\
\hline
\end{tabular}

a This table indicates federal-aid funds obligated and highway improvements authorized in fiscal year 1990.

b Calculated values available for Items 1, 4-8, 10, 11; others estimated by interpolation. Increase rural energy consumption by $20 \%$ for urban construction.

c Values in square brackets were calculated for the typical 40 - $\mathrm{ft}$ bridge span $\left(10^{9} \mathrm{Btu} / 40 \mathrm{ft}\right)$. These numbers are not necessarily exact multiples of the one-mile values and were not obtained by merely dividing the one-mile values by 132 (i.e., $5,280 / 40=132$ ).

Source: Federal Highway Administration (1990). 


\section{HIGHWAY-INFRASTRUCTURE INVENTORY}

\subsection{ROADWAYS}

Table 4.1 defines U.S. road mileage by population area (i.e., rural or urban) in terms of six surface types. This table makes it easy to distinguish the number of miles (total and by population area) for high-type flexible, composite, and rigid pavements. The surface type associated.with lowand intermediate-paved roads and streets is less readily identifiable, but the footnotes to the table are helpful in defining them as flexible pavements.

\subsection{BRIDGES}

A 1989 report to Congress, The Status of the Nation's Highways and Bridges, reveals that the nation faces an annual repair bill of approximately $\$ 19$ billion for replacement of deficient federal-aid system bridges (Secretary of Transportation 1989). Rehabilitation represents an annual cost of approximately $\$ 12.1$ billion, so that about $\$ 31.1$ billion is needed annually for both replacement and rehabilitation of deficient federal-aid system bridges. Off-system bridges also need to be considered. Tables 4.2 and 4.3 provide various bridge inventory data. 
TABLE 4.1 1990 Public Road and Street Mileage

\begin{tabular}{|c|c|c|c|}
\hline Surface Type & Urban Miles & Rural Miles & $\begin{array}{c}\text { Total Miles } \\
\text { by Surface } \\
\text { Type }\end{array}$ \\
\hline Unpaved & 41,126 & $1,579,880$ & $1,621,006$ \\
\hline \multicolumn{4}{|l|}{ Paved } \\
\hline Low $^{a}$ & 86,373 & 406,352 & 492,725 \\
\hline Intermediate $^{b}$ & 191,540 & 346,560 & 538,100 \\
\hline \multicolumn{4}{|l|}{ High } \\
\hline Flexible $^{c}$ & 326,679 & 661,269 & 987,948 \\
\hline Composite $^{d}$ & 41,581 & 73,473 & 115,054 \\
\hline Rigid $^{e}$ & 70,064 & 55,254 & 125,318 \\
\hline Total miles by population & 757,363 & $3,122,788$ & $3,880,151$ \\
\hline
\end{tabular}

a For low-paved road, bituminous surface course is less than 1-in. thick.

b Intermediate-paved road consists of a mixed bituminous or bituminouspenetration road on a flexible base and has a combined surface and base thickness of less than 7 in.

c Flexible surface consists of bituminous asphalt concrete (BAC).

d Composite is a combination of both PCC and BAC.

e Rigid refers to PCC.

Source: Federal Highway Administration (1990). 
TABLE 4.2 Estimated Cost of Replacing or Rehabilitating Currently Deficient Bridges Eligible for the Highway Bridge Replacement and Rehabilitation Program, Including Federal and State Shares

\begin{tabular}{|c|c|c|c|c|c|}
\hline System & $\begin{array}{c}\text { Number of Bridges Eligible for } \\
\text { Replacement or Rehabilitation } \\
\text { (sufficiency rating }<50)^{\mathfrak{a}}\end{array}$ & $\begin{array}{l}\text { Estimated } \\
\text { Replacement } \\
\text { Cost }\left(\$ 10^{9}\right) \\
\end{array}$ & $\begin{array}{l}\text { Number of Bridges Eligible } \\
\text { for Rehabilitation } \\
{\text { (sufficiency rating } 50-80)^{\mathrm{a}}}\end{array}$ & $\begin{array}{l}\text { Estimated } \\
\text { Rehabilitation } \\
\text { Cost }\left(\$ 10^{9}\right) \\
\end{array}$ & $\begin{array}{c}\text { Total } \\
\text { Cost } \\
\left(\$ 10^{9}\right) \\
\end{array}$ \\
\hline Interstate $^{\mathrm{b}}$ & 811 & 1.0 & 4,238 & 2.5 & 3.5 \\
\hline Primary & 8,324 & 8.2 & 13,379 & 5.3 & 13.5 \\
\hline Secondary & 13,538 & 4.7 & 14,295 & 2.1 & 6.8 \\
\hline Urban & 4,657 & 5.1 & 5,423 & 2.2 & 7.3 \\
\hline Total federal aid & 27,330 & 19.0 & 37,335 & 12.1 & 31.1 \\
\hline Off-system & 102,949 & 15.8 & 48,136 & 3.8 & 19.6 \\
\hline Total & 130,279 & 34.8 & 85,471 & 15.9 & 50.7 \\
\hline
\end{tabular}

a Bridge sufficiency ratings explained in Section 5.1.

b Interstate bridges are also eligible for funding under the Interstate Resurfacing, Restoration, Rehabilitation and Reconstruction Program.

Source: Secretary of Transportation (1989). 
TABLE 4.3 Estimated Investment Requirements by All Units of Government to Eliminate All

Existing and Accruing Federal-Aid System Bridge Deficiencies, 1987-2005 ( $\$ 10^{6}$ [1987 dollars])

\begin{tabular}{|c|c|c|c|c|c|c|}
\hline $\begin{array}{c}\text { Federal-Aid } \\
\text { System }\end{array}$ & Rehabilitation & Widening & Replacement & $\begin{array}{c}\text { Total } \\
\text { Accuring }\end{array}$ & $\begin{array}{c}\text { Total } \\
\text { Backlog }\end{array}$ & Total \\
\hline Interstate & 12,052 & 1,521 & 11,031 & 11,033 & 13,600 & 24,633 \\
\hline Primary & 8,564 & 3,154 & 15,058 & 7,895 & 18,882 & 26,777 \\
\hline Secondary & 1,467 & 670 & 5,334 & 1,635 & 5,836 & 7,471 \\
\hline Urban & 3,299 & 1,351 & 8,416 & 3,173 & 9,894 & 13,067 \\
\hline Total federal aid & 25,412 & 6,696 & 39,839 & 23,736 & 48,211 & 71,947 \\
\hline Off-system & 2,195 & 1,215 & 17,575 & 1,605 & 19,380 & 20,985 \\
\hline Total & 27,607 & 7,911 & 57,414 & 25,341 & 67,591 & 92,932 \\
\hline
\end{tabular}

Source: Secretary of Transportation (1989). 


\section{INFRASTRUCTURE LIFE EXPECTANCY AND TRAFFIC-TIME-DELAY ESTIMATES}

\subsection{REVIEW OF CURRENT ROADWAY AND BRDGE AGES}

The serviceability of roadway pavements with respect to traffic flow is measured by the "present serviceability rating" (PSR). The PSR is determined by correlating user opinions with measurements of road roughness (as measured by the roughmeter or profilometer), cracking, patching, and rutting. The PSR is formulated by the rating of a series of pavements by a group of panel members, who drive the roadway and rate it from 0 to 5: 0 being impassable and 5 being perfect (Yoder and Witczak 1975, p. 648). Table 5.1 describes each category.

A similar type of indexing scheme is applied by the Federal Highway Administration (FHWA), in consultation with the states, to establish general bridge priorities. Each bridge inventoried is assigned a sufficiency rating: the lower the sufficiency rating, the higher the priority for replacement or rehabilitation. The sufficiency rating is made on the basis of the following general categories and relative percentages (Secretary of Transportation 1989):

$55 \%$ - structural adequacy and safety

$30 \%$ - serviceability and functional obsolescence

$\underline{15 \%}$ - essentially for public use

$100 \%$.

From a state's inventory data, the FHWA compiles the Highway Bridge Replacement and Rehabilitation Program (HBRRP) selection list for that state. The list includes all deficient bridges with a sufficiency rating of 80 or less. All of these bridges are eligible for rehabilitation. Bridges with a sufficiency rating of less than 50 are also eligible for replacement. The FHWA requires that a state consider all feasible alternatives, including rehabilitation, before they approve replacement. Rehabilitation, where feasible, is usually less expensive than replacement.

The fact that a bridge is "deficient," either structurally or functionally, does not imply that it is likely to collapse or that it is unsafe. With proper load posting and enforcement, most structurally deficient bridges can continue to serve traffic that is restricted to the posted maximum loads. Some functionally obsolete bridges have geometric deficiencies (for example, they may be narrower than modern standards require) that can be mitigated, but not eliminated, by the use of roadway striping, signs, signals, and energy-absorbing crash barriers. 
TABLE 5.1 Present Serviceability Rating

\begin{tabular}{|c|c|c|}
\hline PSR & Verbal Rating & Description \\
\hline 5 & Very good & $\begin{array}{l}\text { Only new (or nearly new) pavements are likely to be smooth enough and } \\
\text { sufficiently free of cracks and patches to qualify for this category. All } \\
\text { pavements constructed or resurfaced recently should be rated in this category. }\end{array}$ \\
\hline 4 & Good & $\begin{array}{l}\text { Pavements in this category, although not quite as smooth as those described } \\
\text { above, give first-class ride and exhibit few, if any, visible signs of surface } \\
\text { deterioration. Flexible pavements may be beginning to show evidence of } \\
\text { rutting and fine random cracks. Rigid pavements may be beginning to show } \\
\text { evidence of slight surface deterioration, such as minor cracks and spalling. }\end{array}$ \\
\hline 3 & Fair & $\begin{array}{l}\text { The riding qualities of pavements in this category are noticeably inferior to } \\
\text { those of new pavements and may be barely tolerable for high-speed traffic. } \\
\text { Surface defects of flexible pavements may include rutting, map cracking, and } \\
\text { more or less extensive patching. Rigid pavements in this group may have a few } \\
\text { joint failures, faulting and cracking, and some pumping. }\end{array}$ \\
\hline 2 & Poor & $\begin{array}{l}\text { Pavements that have deteriorated to such an extent that they are in need of } \\
\text { resurfacing. }\end{array}$ \\
\hline 1 & Very poor & $\begin{array}{l}\text { Pavements that are in an extremely deteriorated condition and may even need } \\
\text { complete reconstruction. }\end{array}$ \\
\hline & & $\cdot \cdot$ \\
\hline
\end{tabular}

Source: Secretary of Transportation (1989).

\subsection{EXPECTED ROADWAY LIFE}

Life expectancies for pavements depend on several factors, including design, traffic volumes, and environmental conditions. The design process is a trade-off between costs and life expectancy. A large initial investment will generally reduce maintenance costs and extend the service life of the pavement. Because pavements are designed on the basis of predicted traffic volume, a significant increase in traffic volume, especially in trucks, will decrease the life of the pavement and increase maintenance costs. Freeze/thaw fluctuations in the weather are extremely detrimental to both ACC and PCC pavements. Also, water penetration into the pavement or at the base can cause such problems as pumping under concrete and asphalt pavements, as well as stripping of the cement from asphalt pavement. 
Life expectancies for ACC pavements are typically 10-20 years. A 20-year design life usually requires a maintenance overlay at 10 years. Maintenance overlays are usually less than 1-in. thick and are meant to restore skid resistance, improve rideability, and extend service life. Structural overlays, the other type of overlay, are thicker than 1 in. and are used to enhance or restore structural adequacy of pavement.

There are three types of PCC pavements: plain or jointed nonreinforced, jointed reinforced, and continuously reinforced. If carefully constructed and maintained, PCC pavements can easily last longer than the expected design life.

An expected roadway life of 20 years will be used in all subsequent analyses. Twenty years is a widely quoted average roadway life, although some roads may last much longer, while others may last 10 years or less before major reconstruction is required. Care taken during the construction process, the quality of materials used, and vehicle traffic volumes and axle weights are key factors in determining roadway durability.

\subsection{EXPECTED BRIDGE LIFE}

Life expectancies for bridges also depend on such factors as design, materials quality and types selected, traffic volumes, and environmental conditions (for example, weather and temperature variations, use of road salts on decks, scouring beneath the bridge).

Since the construction of steel bridges has become rare, reinforced concrete (in many different forms) is now the construction standard in the bridge industry. A typical life of 50 years for reinforced concrete bridges and an average interval of 15 years between deck rehabilitations are realistic time periods for planning and forecasting purposes.

\subsection{CONSTRUCTION AND MAINTENANCE TIME-PERIOD REQUIREMENTS}

Construction and maintenance of highways and bridges can cause traffic delays resulting in an increase in fuel consumption per mile of travel. Because finite average data regarding construction and maintenance time periods were not readily available, reasonable estimates were developed. Table 5.2 presents these estimates and associated assumptions. 
TABLE 5.2 Estimated Construction and Maintenance Time Periods and Traffic Delays

\begin{tabular}{|c|c|c|c|}
\hline \multirow[b]{2}{*}{ Activity } & \multirow[b]{2}{*}{$\begin{array}{l}\text { Number of } \\
\text { Work Days }^{\mathrm{a}}\end{array}$} & \multicolumn{2}{|c|}{ Traffic-Delay Periods $^{b}$} \\
\hline & & $\begin{array}{c}\text { Hours of } \\
\text { Viable Traffic }\end{array}$ & $\begin{array}{c}\text { Number of } \\
\text { Work-Day Hours }\end{array}$ \\
\hline $\begin{array}{l}\text { Total bridge replacement/ } \\
\text { construction }\end{array}$ & 84 & 1,512 & 840 \\
\hline Bridge repairs ${ }^{c}$ & 35 & 630 & 350 \\
\hline \multicolumn{4}{|l|}{ New road construction ${ }^{d}$} \\
\hline \multicolumn{4}{|l|}{ Project size } \\
\hline Large & 300 & 5,400 & 3,000 \\
\hline Medium & 200 & 3,600 & 2,000 \\
\hline Small & 75 & 1,350 & 750 \\
\hline ACC repaving ${ }^{d}$ & 2 & 36 & 20 \\
\hline PCC repaving ${ }^{d}$ & 6 & 108 & 60 \\
\hline
\end{tabular}

a Average of 5.0 working days per week.

b Viable traffic for 18 hours per day and 10-hour working days.

c Per 40-ft bridge (typical).

d Per lane-mile.

Source: Estimates derived from discussions with construction industry personnel (unpublished information) in 1992. 


\section{ENERGY IMPACTS}

\subsection{ENERGY EXPENDED}

Energy expenditures occur in four major ways:

1. Use of a road or bridge by motorized vehicular traffic,

2. Production of component construction materials,

3. Actual road or bridge construction, and

4. Repairs made during the total life cycle of a road or bridge (i.e., during new materials production, additional construction or materials installation, and increased traffic delays).

Vehicle energy expended for vehicular traffic, Stage 1, can be affected if the coefficient of friction of the roadway changes. In calculations relating to Stage 1, all energy-consumption variations are attributed to the coefficient of friction change. This assumption simultaneously requires that there be no changes in other conditions, including individual vehicle mileage (mpg), different tire designs, highway alignments and grades, and other vehicle design factors. (These other changes are outside the purview of the discussion in this section.)

Thus, the only way that a highway-infrastructure change will affect energy consumption is by changing the coefficient of friction on road surfaces. Bridge coefficients of friction are effectively inconsequential, because bridges are relatively insignificant "points" when both total vehicle miles of travel and the ratio of total bridge-miles to total road-miles are considered. In addition, bridge mileage is typically included in the highway mileage, and the bridge surface is often the same type of surface as the adjoining roadway. Therefore, only changes to the coefficient of rolling friction, $f$, for roads will be studied.

Calculations relating to the energy required to produce construction materials, Stage 2, will use the materials production statistics presented earlier in Table 3.2.

Stage 3 involves energy consumption in essentially three areas: (1) energy consumption relating to the production of materials, (2) actual construction energy demands, and (3) energy impacts associated with increased traffic delays. The first portion of Table 3.1 is useful for area 1 questions. The second portion of Table 3.2, showing energy consumption for in-place secondary (completed) materials, will be useful for area 2. Congestion-related energy use (area 3) will require supplemental calculations. 
Finally, energy-consumption calculations relating to the total life-cycle of a road or bridge, Stage 4, must consider (1) frequency and type of repairs, (2) energy consumption relating to the production of replacement materials, (3) repair, construction or installation energy requirements, and (4) energy impacts associated with increased traffic delays. The information in Table 3.2 will again be useful, and duration and volume estimates for traffic-delay estimates will be required.

\subsection{ENERGY CONSERVED}

For purposes of this study, energy is conserved when any of the following five conditions, either singly or collectively, is satisfied:

1. Rolling frictional forces are lowered (frictional forces may become lower as a road surface ages);

2. Production of additional construction materials is not required;

3. New construction is deferred (i.e., longer product life);

4. Fewer or less frequent repairs are necessary; or

5. Vehicles are delayed less frequently.

Technological changes in product development or in the development of more energyefficient construction materials can change the quantities of energy expended; thus, energy not required can be viewed as energy conserved. These types of energy requirements (or savings) are outside the scope of the major purpose of this highway-infrastructure analysis. Therefore, energy conserved during the production of the materials themselves or the construction process will not be analyzed in detail nor will they be considered major sources of energy conservation.

\subsection{OVERVIEW OF POSSIBLE STRATEGIES}

The following representative list of potential strategies highlights ways in which the total energy utilization of the United States can be affected by changes in our nation's highway infrastructure:

1. Roadway riding surfaces are changed such that the coefficient of rolling friction is reduced.

2. Effective lives of roads are extended. 
3. Effective lives of bridges are extended.

4. Less frequent and extensive maintenance is required for roads.

5. Less frequent and extensive maintenance is required for bridges.

6. Smaller volume of materials is required for roads.

7. Stronger, smaller bridges become more practicable.

8. Vehicular traffic congestion is reduced.

The preceding list of potential strategies is certainly not inclusive of all possible strategies, but it is representative, because the most significant and likely strategies are presented. 


\section{DEVELOPMENT OF A PROCESS FOR EVALUATION OF ENERGY IMPACTS}

\subsection{REVIEW OF POTENTIAL ANALYSIS TECHNIQUES}

Since energy and not economic factors is the major consideration in this study, such economic analysis techniques as net present worth, equivalent uniform annual cost, benefit-cost (or cost-benefit), and internal rate of return are not applicable.

When criteria values (e.g., energy consumed or saved) are not appropriate for conversion into monetary values, the use of numerical scores in a rating or ranking technique is helpful in comparing the relative worth of alternatives. Rating or ranking analysis techniques typically have many applications. The basic equation used in this technique can be stated as follows:

$$
S_{i}=\sum_{j=1}^{N} K_{j} V_{i j}
$$

where

$$
\begin{aligned}
& S_{i}=\text { total value of score of alternative } i, \\
& K_{j}=\text { weight placed on criterion } j \text {, and } \\
& V_{i j}=\text { relative value achieved by criterion } j \text { for alternative } i .
\end{aligned}
$$

Criteria may be equally weighted $\left(\mathrm{K}_{\mathrm{j}}=1\right)$, or variable weights may be assigned according to the following equation:

$$
K_{j}=\frac{W_{j}}{\sum_{j=1}^{N} W_{j}}
$$

where

$$
\begin{aligned}
& \mathrm{K}_{\mathrm{j}}=\text { weighting factor of objective } \mathrm{j} \text {, and } \\
& \mathrm{W}_{\mathrm{j}}=\text { relative weight for objective } \mathrm{j} \text {. }
\end{aligned}
$$

A ranking and rating evaluation can be an attractive technique because a wide variety of criteria and viewpoints can be considered. Reducing all factors to a single number is a convenient and 
quantifiable means of rating different alternatives. The principal disadvantage is that dependence on a numerical outcome masks the major issues underlying the selection and the trade-offs involved.

Ranking methods also have another inherent problem in that the mathematical form of the rating formula (i.e., Equation 1 ) is a summation of the products of the criteria weight and the relative value. The scale of measurement must be a constant interval (e.g., temperature) for this relationship to be mathematically correct. If the ranking values are ordinal (such as numbering or ordering variables), the ranking formula may not be directly applicable.

Two further problems are the ability to vary the final rank order by merely changing the ranking of objectives and the ability to communicate the magnitude of problems correctly when presenting final results to decision makers (Garber and Hoel 1988). With respect to the first problem, subjectivity in ranking objectives can change the final result. The second problem involves visualization and comprehension. When decision makers (and citizens) are given only numbers to evaluate, it is often difficult to visualize how and why particular results were derived. People typically think in a logical and sequential manner, and they can only judge among alternatives when those alternatives are presented realistically. A single ranking or rating is sometimes viewed as being somewhat abstract and detached.

Other potential numerical analysis techniques to consider include the following:

1. Multiple linear regression,

2. Cross classification,

3. Multivariate analysis,

4. Analysis of variance,

5. Factor analysis,

6. Simulation, and

7. Sensitivity analysis.

Many other numerical analysis techniques are possible, since there is an almost infinite number of analytical models and analysis techniques that have some potential. 
Many of the more statistical techniques listed above have two fundamental disadvantages with respect to energy use comparisons. For valid results, the data must be (1) statistically based and (2) extensive in amount. Both the statistical nature and the extensiveness of empirical data for statistical energy analyses are questionable. These factors lessen the attractiveness of using recognized, highly statistical procedures.

The last technique listed above, that of performing sensitivity analyses, may take many different forms, but it appears to have potential in subsequent analyses.

A final series of potential analysis techniques that certainly should not be discounted will be referred to broadly as "graphical procedures." This category includes techniques such as the following:

1. Graphs (pie charts, histograms, etc.),

2. Families of curves,

3. Nomographs (specialized graphs, often consisting of multiple, dependent graphs),

4. Venn diagrams, and

5. Visual charts or pictures that depict selected data comparisons.

Many of these visual presentations are highly dependent on the results from earlier numerical analyses. No single graphical procedure emerges as the exact and only way to analyze energy consumption and saving comparisons.

\subsection{TECHNIQUE SELECTION}

After reviewing the advantages and disadvantages of the analytical techniques listed in Section 7.1, two techniques emerged as the most straightforward and useful. One technique is sensitivity analysis, because this technique is a viable way to represent two-dimensional parametric changes in an easily understood matrix context. Thus, sensitivity analyses using percent changes, plus other policy, construction, or maintenance changes, will be used to depict various strategies and representative energy impacts for each alternative strategy (Section 6.3). 
The other technique is somewhat similar in nature and merely involves tabular presentations that depict various calculation results as assumptions or parameters vary. Thus, sensitivity analyses using matrices and tables will be used. 


\section{ENERGY CONSUMPTION IMPACTS UNDER VARIOUS SCENARIOS}

\subsection{SCENARIO 1: CHANGE IN ROLLING RESISTANCE COEFFICIENT}

How will annual U.S. energy consumption change if the coefficient of rolling friction on various roads is reduced?

Assumptions:

1. For a smooth asphalt surface, $f_{R}$ is 0.015 ; for a smooth PCC surface, $f_{R}$ is 0.017 (Limpert 1978, Table 18-1).

2. A 10-year maintenance overlay cycle for asphalt (rigid and composite) pavements and a 20-year surface replacement/rehabilitation cycle for PCC pavements are assumed.

3. On the basis of Table 4.1, an average of one-tenth (urban) and one-twentieth (rural) of total "high-surface" -type miles are assumed to be resurfaced each year (replacement with same pavement type is assumed):

\begin{tabular}{crr} 
& \multicolumn{2}{c}{ Road Miles } \\
\cline { 2 - 3 } Surface & \multicolumn{1}{c}{ Urban } & \multicolumn{1}{c}{ Rural } \\
\hline ACC & 36,826 & 73,474 \\
PCC & 3,503 & 2,763
\end{tabular}

4. Average urban speed is $35 \mathrm{mi} / \mathrm{h}$, while average rural speed is $55 \mathrm{mi} / \mathrm{h}$ (Table 3.1).

Results for this scenario are presented in Tables 8.1-8.3.

Although reducing a vehicle's coefficient of rolling friction between the tires and the roadway may be good in terms of energy savings, it also may adversely affect vehicle performance and handling. Problems with cornering and stopping may be encountered. These effects may be slightly less serious for newer vehicles with antilock brakes, but the increased risks and reduction in overall safety must be carefully evaluated against the suggested energy savings. 
TABLE 8.1 Rolling Resistance Energy Savings, $5 \% f_{R}$ Reduction $\left(10^{6} \mathrm{Btu}\right)$

\begin{tabular}{|c|c|c|c|c|c|c|}
\hline \multirow[b]{3}{*}{ Year } & \multicolumn{4}{|c|}{ Annual Energy Savings } & \multirow{3}{*}{$\begin{array}{c}\text { Annual } \\
\text { Incremental } \\
\text { Savings }\end{array}$} & \multirow{3}{*}{$\begin{array}{c}\text { Cumulative } \\
\text { Savings }\end{array}$} \\
\hline & \multicolumn{2}{|c|}{ Urban } & \multicolumn{2}{|c|}{ Rural } & & \\
\hline & $\mathrm{ACC}$ & PCC & $\mathrm{ACC}$ & PCC & & \\
\hline 1 & 78.5 & 7.95 & 28.0 & 1.19 & 115.7 & 115.7 \\
\hline 2 & 157 & 15.9 & 56.0 & 2.39 & 231.3 & 347.0 \\
\hline 3 & 236 & 23.8 & 84.0 & 3.58 & 347.0 & 693.9 \\
\hline 4 & 314 & 31.8 & 112 & 4.77 & 462.6 & 1,157 \\
\hline 5 & 393 & 39.7 & 140 & 5.96 & 578.3 & 1,735 \\
\hline 6 & 471 & 47.7 & 168 & 7.16 & 693.9 & 2,429 \\
\hline 7 & 550 & 55.6 & 196 & 8.35 & 809.6 & 3,238 \\
\hline 8 & 628 & 63.6 & 224 & 9.54 & 925.2 & 4,164 \\
\hline 9 & 707 & 71.5 & 252 & 10.7 & 1,041 & 5,204 \\
\hline 10 & 785 & 79.5 & 280 & 11.9 & 1,157 & 6,361 \\
\hline 11 & $\mathbf{a}$ & 87.4 & a & 13.1 & 100.5 & 6,461 \\
\hline 12 & a & 95.3 & a & 14.3 & 109.7 & 6,571 \\
\hline . & . & . & . & . & . & . \\
\hline . & . & . & . & . & . & . \\
\hline . & . & . & . & . & . & . \\
\hline 19 & a & 151 & a & 22.7 & 173.6 & 7,595 \\
\hline 20 & $\mathbf{a}$ & 159 & $\mathbf{a}$ & 23.9 & 182.8 & 7,777 \\
\hline
\end{tabular}

Average annual energy savings $=388.9$

a Steady state is reached in Year 11 and maintained through Year 20. 
TABLE 8.2 Rolling Resistance Energy Savings, $10 \% \mathbf{f}_{\mathrm{R}}$ Reduction $\left(10^{6} \mathrm{Btu}\right)$

\begin{tabular}{|c|c|c|c|c|c|c|}
\hline \multirow[b]{3}{*}{ Year } & \multicolumn{4}{|c|}{ Annual Energy Savings } & \multirow{3}{*}{$\begin{array}{c}\text { Annual } \\
\text { Incremental } \\
\text { Savings }\end{array}$} & \multirow{3}{*}{$\begin{array}{c}\text { Cumulative } \\
\text { Savings }\end{array}$} \\
\hline & \multicolumn{2}{|c|}{ Urban } & \multicolumn{2}{|c|}{ Rural } & & \\
\hline & $\mathrm{ACC}$ & PCC & $\mathrm{ACC}$ & PCC & & \\
\hline 1 & 157 & 15.9 & 56.0 & 2.39 & 231.3 & 231.3 \\
\hline 2 & 314 & 31.8 & 11.2 & 4.77 & 462.6 & 693.9 \\
\hline 3 & 471 & 47.7 & 168 & 7.16 & 693.9 & 1,388 \\
\hline 4 & 628 & 63.6 & 224 & 9.54 & 925.2 & 2,313 \\
\hline 5 & 785 & 79.5 & 280 & 11.9 & 1,157 & 3,470 \\
\hline 6 & 942 & 95.4 & 336 & 14.3 & 1,388 & 4,857 \\
\hline 7 & 1,100 & 111 & 392 & 16.7 & 1,619 & 6,477 \\
\hline 8 & 1,260 & 127 & 448 & 19.1 & 1,850 & 8,327 \\
\hline 9 & 1,410 & 143 & 504 & 21.5 & 2,082 & 10,410 \\
\hline 10 & 1,570 & 159 & 560 & 23.9 & 2,313 & 12,720 \\
\hline 11 & a & 175 & a & 26.2 & 201.1 & 12,920 \\
\hline \multirow[t]{2}{*}{12} & a & 191 & $\mathbf{a}$ & 28.6 & 219.3 & 13,140 \\
\hline & . & . & $\cdot$ & . & . & . \\
\hline . & . & . & . & . & . & . \\
\hline . & . & . & . & . & . & . \\
\hline 19 & a & 302 & a & 45.3 & 347.3 & 15,190 \\
\hline 20 & a & 318 & a & 47.7 & 365.5 & 15,550 \\
\hline
\end{tabular}

a Steady state is reached in Year 11 and maintained through Year 20. 
TABLE 8.3 Rolling Resistance Energy Savings, $15 \% \mathrm{f}_{\mathrm{R}}$ Reduction $\left(10^{6} \mathrm{Btu}\right)$

\begin{tabular}{|c|c|c|c|c|c|c|}
\hline \multirow[b]{3}{*}{ Year } & \multicolumn{4}{|c|}{ Annual Energy Savings } & \multirow{3}{*}{$\begin{array}{l}\text { Annual } \\
\text { Incremental } \\
\text { Savings }\end{array}$} & \multirow{3}{*}{$\begin{array}{c}\text { Cumulative } \\
\text { Savings }\end{array}$} \\
\hline & \multicolumn{2}{|c|}{ Urban } & \multicolumn{2}{|c|}{ Rural } & & \\
\hline & $\mathrm{ACC}$ & PCC & $\mathrm{ACC}$ & PCC & & \\
\hline 1 & 236 & 23.8 & 84.0 & 3.58 & 347.4 & 347.4 \\
\hline 2 & 471 & 47.7 & 168 & 7.16 & 693.9 & 1041 \\
\hline 3 & 707 & 71.5 & 252 & 10.7 & 1,041 & 2,082 \\
\hline 4 & 942 & 95.4 & 336 & 14.3 & 1,388 & 3,470 \\
\hline 5 & 1,180 & 119 & 420 & 17.9 & 1,735 & 5,204 \\
\hline 6 & 1,410 & 143 & 504 & 21.5 & 2,082 & 7,286 \\
\hline 7 & 1,650 & 167 & 588 & 25.1 & 2,429 & 9,715 \\
\hline 8 & 1,880 & 191 & 672 & 28.6 & 2,776 & 12,490 \\
\hline 9 & 2,120 & 215 & 756 & 32.2 & 3,123 & 15,610 \\
\hline 10 & 2,360 & 239 & 840 & 35.8 & 3,470 & 19,080 \\
\hline 11 & a & 262 & a & 39.4 & 3,066 & 19,380 \\
\hline 12 & a & 286 & a & 42.9 & 329.0 & 19,710 \\
\hline$\cdot$ & $\cdot$ & $\cdot$ & . & . & . & . \\
\hline$\cdot$ & $\cdot$ & · & . & . & $\cdot$ & . \\
\hline$\cdot$ & $\cdot$ & $\cdot$ & . & $\cdot$ & • & . \\
\hline 19 & a & 45.3 & a & 68.0 & 520.9 & 22,780 \\
\hline 20 & a & 47.7 & a & 71.6 & 548.3 & 23,330 \\
\hline
\end{tabular}

a Steady state is reached in Year 11 and maintained through Year 20. 


\subsection{SCENARIO 2: INCREASED ROAD LIFE CYCLES}

What impact will longer-lasting roads have on annual U.S. energy consumption?

Assumptions:

1. Twenty-year average road life is extended in either 1 -year $(+5 \%), 2$-year $(+10 \%)$, or 3-year $(+15 \%)$ increments.

2. "Reconstruction" energy construction rates from Table 3.3 are assumed.

3. Year 1 is actually equivalent to Year 21, because energy savings for longer road life through reconstruction are not realized until the end of another road life cycle.

Table 8.4 reveals the magnitude of average annual benefits in energy savings for longerlasting roads. Thus, higher strength, longer lasting materials for highway construction (such as improved concretes, aggregates, polymeric rebars, and other materials) will provide definite, but not immediate, energy savings. 
TABLE 8.4 Energy Savings from Increased Road Life $\left(10^{12} \mathrm{Btu}\right)$

\begin{tabular}{|c|c|c|c|c|c|c|c|c|c|}
\hline \multirow[b]{2}{*}{ Year $^{\mathrm{a}}$} & \multicolumn{3}{|c|}{ Increase of $>1$ Year $(+5 \%)$} & \multicolumn{3}{|c|}{$\begin{array}{c}\text { Increase of }>2 \text { Years } \\
(+10 \%)\end{array}$} & \multicolumn{3}{|c|}{$\begin{array}{c}\text { Increase of }>3 \text { Years } \\
(+15 \%)\end{array}$} \\
\hline & Rural & Urban & Total & Rular & Urban & Total & Rural & Urban & Total \\
\hline $1(21)$ & 10.2 & 3.8 & 14.0 & 10.2 & 3.8 & 14.0 & - & - & \\
\hline $2(22)$ & - & - & - & 10.2 & 3.8 & 14.0 & 10.2 & 3.8 & 14.0 \\
\hline $3(23)$ & - & - & - & - & - & - & 10.2 & 3.8 & 14.0 \\
\hline $\begin{array}{l}\text { Average annual } \\
\text { energy savings } \\
\text { (20-year life cycle) }\end{array}$ & 0.5 & 0.2 & 0.7 & 1.0 & 0.4 & 1.4 & 1.5 & 0.6 & 2.1 \\
\hline
\end{tabular}

a Year outside parentheses is year of realized benefit; year within parentheses is actual year from time of initial reconstruction. 


\subsection{SCENARIO 3: BRIDGE LIFE EXTENDED}

What annual energy savings will result from increased life cycles for bridges?

Assumptions:

1. Fifty-year average bridge life is extended in either 2.5 -year $(+5 \%)$, 5-year $(+10 \%)$, or 7.5 -year $(+15 \%)$ increments.

2. "Bridge Replacement" energy construction rates and number of bridges replaced annually from Table 3.3 are assumed.

3. Year 2.5 is actually equivalent to Year 52.5, because energy savings from longer lasting bridges are not realized until the end of a bridge's life cycle.

4. Two 40-ft spans are assumed to represent a typical bridge.

Table 8.5 presents information about potential energy savings from longer bridge life. 
TABLE 8.5 Energy Savings from Increased Bridge Life $\left(10^{12} \mathrm{Btu}\right)$

\begin{tabular}{|c|c|c|c|c|c|c|c|c|c|}
\hline \multirow[b]{2}{*}{ Year $^{\mathrm{a}}$} & \multicolumn{3}{|c|}{$\begin{array}{c}\text { Increase of }>1 \text { Year } \\
(+5 \%)\end{array}$} & \multicolumn{3}{|c|}{$\begin{array}{c}\text { Increase of }>2 \text { Years } \\
(+10 \%)\end{array}$} & \multicolumn{3}{|c|}{$\begin{array}{c}\text { Increase of }>3 \text { Years } \\
(+15 \%)\end{array}$} \\
\hline & Rural & Urban & Total & Rural & Urban & Total & Rural & Urban & Total \\
\hline $2.5(52.5)$ & 7.1 & 2.2 & 9.3 & 7.1 & 2.2 & 9.3 & - & - & - \\
\hline $5.0(55)$ & - & - & - & 7.1 & 2.2 & 9.3 & 7.1 & 2.2 & 9.3 \\
\hline $7.5(57.5)$ & - & - & - & - & - & - & 7.1 & 2.2 & 9.3 \\
\hline $\begin{array}{l}\text { Average annual } \\
\text { energy savings } \\
\text { (50-year life-cycle) }\end{array}$ & 0.14 & 0.05 & 0.19 & 0.28 & 0.09 & 0.37 & 0.43 & 0.13 & 0.56 \\
\hline
\end{tabular}

a Year outside parentheses is year of realized benefit; year within parentheses is actual year from time of initial reconstruction. 


\subsection{SCENARIO 4: LESS ROAD MAINTENANCE REQUIRED}

What U.S. energy savings will result from road maintenance being required less frequently?

Assumptions:

1. Annual rural and urban miles for "restoration and rehabilitation" and "resurfacing" and associated energy consumption rates from Table 3.3 are assumed.

2. Current restoration and rehabilitation are on a 20 -year cycle, and resurfacing is on a 10 -year cycle.

3. Increases of $5 \%, 10 \%$, and $15 \%$ (i.e., additional 1,2 , and 3 years before restoration and rehabilitation and $0.5,1$, and 1.5 years for resurfacing) are evaluated.

4. Less-frequently-required maintenance implies that maintenance is needed less often, but it is not neglected.

Tables 8.6-8.8 present energy conservation estimates based on less-frequent road maintenance. 
TABLE 8.6 Energy Savings from Less-Frequently-Required Road Maintenance, $+5 \%$ Increase $\left(10^{12} \mathrm{Btu}\right)$

\begin{tabular}{|c|c|c|c|c|c|c|}
\hline \multirow[b]{2}{*}{ Year $^{2}$} & \multicolumn{3}{|c|}{$\begin{array}{l}\text { 5\% Restoration and } \\
\text { Rehabilitation Improvement } \\
(+1 \text { year })\end{array}$} & \multicolumn{3}{|c|}{$\begin{array}{l}5 \% \text { Resurfacing } \\
\text { Improvement } \\
(+0.5 \text { year })\end{array}$} \\
\hline & Rural & Urban & Total & Rural & Urban & Total \\
\hline $1(11)$ & - & - & - & 1.58 & 0.35 & $1.93^{b}$ \\
\hline $2(12)$ & - & - & - & - & - & - \\
\hline \multirow[t]{4}{*}{$3(13)$} & - & - & - & - & - & - \\
\hline & . & . & . & . & . & . \\
\hline & . & . & . & . & . & . \\
\hline & . & . & . & . & . & . \\
\hline $11(21)$ & 3.77 & 1.14 & 4.91 & 1.58 & 0.35 & 1.93 \\
\hline $12(22)$ & - & - & - & - & - & - \\
\hline $12(23)$ & - & - & - & - & - & - \\
\hline $14(24)$ & - & - & - & - & - & - \\
\hline $\begin{array}{l}\text { Average annual } \\
\text { energy savings }\end{array}$ & \multicolumn{3}{|c|}{0.347 (rural) } & (urban) & \multicolumn{2}{|c|}{0.439 (total) } \\
\hline
\end{tabular}

a Year outside parentheses is year when first energy savings begin; year within parentheses is the actual year since restoration and rehabilitation or resurfacing was accomplished.

b Reported only one-half of a full-year energy savinggs because increased increment was only 0.5 year. 
TABLE 8.7 Energy Savings from Less-Frequently-Required Road Maintenance, $+10 \%$ Increase $\left(10^{12} \mathrm{Btu}\right)$

\begin{tabular}{|c|c|c|c|c|c|c|}
\hline \multirow[b]{2}{*}{ Year $^{\mathrm{a}}$} & \multicolumn{3}{|c|}{$\begin{array}{c}10 \% \text { Restoration and } \\
\text { Rehabilitation Improvement } \\
(+2 \text { years })\end{array}$} & \multicolumn{3}{|c|}{$\begin{array}{c}10 \% \text { Resurfacing } \\
\text { Improvement } \\
(+1 \text { year }) \\
\end{array}$} \\
\hline & Rural & Urban & Total & Rural & Urban & Total \\
\hline $1(11)$ & - & - & - & 3.16 & 0.70 & 3.86 \\
\hline $2(12)$ & - & - & - & - & - & - \\
\hline $3(13)$ & - & - & - & - & - & - \\
\hline . & . & . & . & . & $\cdot$ & . \\
\hline - & . & . & . & $\cdot$ & $\cdot$ & $\cdot$ \\
\hline . & . & . & . & . & . & . \\
\hline $11(21)$ & 3.77 & 1.14 & 4.91 & - & - & - \\
\hline $12(22)$ & 3.77 & 1.14 & 4.91 & 3.16 & 0.70 & 3.86 \\
\hline $13(23)$ & - & - & - & - & - & - \\
\hline $14(24)$ & - & - & - & - & - & - \\
\hline $\begin{array}{l}\text { Average annual } \\
\text { energy savings }\end{array}$ & \multicolumn{3}{|c|}{0.693 (rural) } & 0.184 (urban) & \multicolumn{2}{|c|}{0.877 (total) } \\
\hline
\end{tabular}

a Year outside parentheses is year when first energy savings begin; year within parentheses is the actual year since restoration and rehabilitation or resurfacing was accomplished. 
TABLE 8.8 Energy Savings from Less-Frequently-Required Road Maintenance, $+15 \%$ Increase $\left(10^{12} \mathrm{Btu}\right)$

\begin{tabular}{|c|c|c|c|c|c|c|}
\hline \multirow[b]{2}{*}{ Year $^{a}$} & \multicolumn{3}{|c|}{$\begin{array}{l}15 \% \text { Restoration and } \\
\text { Rehabilitation Improvement } \\
\text { ( }+3 \text { years })\end{array}$} & \multicolumn{3}{|c|}{$\begin{array}{c}15 \% \text { Resurfacing } \\
\text { Improvement } \\
(+1.5 \text { years }) \\
\end{array}$} \\
\hline & Rural & Urban & Total & Rural & Urban & Total \\
\hline $1(11)$ & - & - & - & 3.16 & 0.70 & 3.86 \\
\hline $2(12)$ & - & - & - & 1.58 & 0.35 & $1.93^{\mathrm{b}}$ \\
\hline $3(13)$ & - & - & - & - & - & - \\
\hline $4(14)$ & - & - & - & - & - & - \\
\hline . & . & . & . & . & . & . \\
\hline . & . & . & . & . & . & . \\
\hline . & . & . & . & . & . & . \\
\hline $11(21)$ & 3.77 & 1.14 & 4.91 & - & - & - \\
\hline $12(22)$ & 3.77 & 1.14 & 4.91 & & & \\
\hline $12(23)$ & 3.77 & 1.14 & 4.91 & 3.16 & 0.70 & 3.86 \\
\hline $14(24)$ & - & - & - & 1.58 & 0.35 & 1.93 \\
\hline $\begin{array}{l}\text { Average annual } \\
\text { energy savings }\end{array}$ & \multicolumn{2}{|c|}{1.04 (rural) } & \multicolumn{2}{|c|}{0.28 (urban) } & \multicolumn{2}{|c|}{$1.32($ total $)$} \\
\hline
\end{tabular}

a Year outside parentheses is year when first energy savings begin; year within parentheses is the actual year since restoration and rehabilitation or resurfacing was accomplished.

b Reported only one-half of a full-year energy savings because increased increment was only 0.5 year. 


\subsection{SCENARIO 5: LESS BRIDGE MAINTENANCE REQUIRED}

What average annual U.S. energy savings will result from less-frequently-needed bridge maintenance?

Assumptions:

1. Typical bridge is assumed to be $80 \mathrm{ft}$, or two $40-\mathrm{ft}$ spans.

2. Number of bridges rehabilitated annually (both major and minor) and associated energy consumption rates from Table 3.3 are assumed. (The construction energy of 40-ft bridges [values in Table 3.3 in brackets] are doubled since $80-\mathrm{ft}$ bridges are assumed.)

3. A 7-year cycle for minor rehabilitation and a 15-year cycle for major rehabilitation are assumed.

Tables 8.9-8.11 show energy savings realized through requiring less-frequent bridge maintenance, with increases of $5 \%, 10 \%$, and $15 \%$ in the time between repairs. 
TABLE 8.9 Energy Savings from Less-Frequently-Required Bridge Maintenance, $+5 \%$ Increase $\left(10^{12}\right.$ Btu)

\begin{tabular}{|c|c|c|c|c|c|c|}
\hline \multirow[b]{2}{*}{ Year $^{\mathrm{a}}$} & \multicolumn{3}{|c|}{$\begin{array}{l}5 \% \text { Minor Rehabilitation } \\
(+0.35 \text { year })\end{array}$} & \multicolumn{3}{|c|}{$\begin{array}{c}5 \% \text { Major Rehabilitation } \\
(+0.8 \text { year })\end{array}$} \\
\hline & Rural & Urban & Total & Rural & Urban & Total \\
\hline $1(8)$ & 0.02 & 0.017 & $0.037^{b}$ & - & - & - \\
\hline $2(9)$ & - & - & - & - & - & - \\
\hline $3(10)$ & - & - & - & - & - & - \\
\hline . & . & - & . & . & . & . \\
\hline - & . & . & . & . & . & . \\
\hline . & . & . & . & . & . & . \\
\hline $15(22)$ & 0.02 & 0.017 & 0.037 & 0.84 & 0.89 & $1.73^{\mathrm{c}}$ \\
\hline $16(23)$ & - & - & - & - & - & - \\
\hline $17(24)$ & - & - & - & - & - & - \\
\hline $18(25)$ & - & - & - & - & - & - \\
\hline $\begin{array}{l}\text { Average annual } \\
\text { energy savings }\end{array}$ & \multicolumn{2}{|c|}{0.059 (rural) } & \multicolumn{2}{|c|}{0.061 (urban) } & \multicolumn{2}{|c|}{0.12 (total) } \\
\hline
\end{tabular}

a Year outside parentheses is year when first energy savings begin; year within parentheses is the actual year since minor or major rehabilitation.

b Reported only 0.35 of full-year energy savings because increment was only 0.35 year.

c Reported only 0.8 of a full-year energy savings because increment was only 0.8 year. 
TABLE 8.10 Energy Savings from Less-Frequently-Required Bridge Maintenance, $+10 \%$ Increase $\left(10^{12} \mathrm{Btu}\right)$

\begin{tabular}{|c|c|c|c|c|c|c|}
\hline \multirow[b]{2}{*}{ Year $^{\mathrm{a}}$} & \multicolumn{3}{|c|}{$\begin{array}{l}\text { 10\% Minor Rehabilitation } \\
(+0.7 \text { year })\end{array}$} & \multicolumn{3}{|c|}{$\begin{array}{c}\text { 10\% Major Rehabilitation } \\
(+1.6 \text { years })\end{array}$} \\
\hline & Rural & Urban & Total & Rural & Urban & Total \\
\hline $1(8)$ & 0.04 & 0.034 & $0.074^{b}$ & - & - & - \\
\hline $2(9)$ & - & - & - & - & - & - \\
\hline $3(10)$ & - & - & - & - & - & - \\
\hline . & . & . & . & . & - & $\cdot$ \\
\hline . & . & . & . & . & . & . \\
\hline . & . & . & . & . & . & . \\
\hline $15(22)$ & 0.04 & 0.034 & 0.074 & 1.05 & 1.12 & 2.17 \\
\hline $16(23)$ & - & - & - & 0.63 & 0.67 & $1.30^{\circ}$ \\
\hline $17(24)$ & - & - & - & - & - & - \\
\hline $18(25)$ & - & - & - & - & - & - \\
\hline . & . & . & . & . & . & . \\
\hline . & . & . & . & . & . & . \\
\hline $\begin{array}{l}\text { Average annual } \\
\text { energy savings }\end{array}$ & & 18 (rur & & urban) & 0.2 & (total) \\
\hline
\end{tabular}

a Year outside parentheses is year when first energy savings begin; year within parentheses is the actual year since minor or major rehabilitation.

b Reported only 0.7 of a full-year energy savings because increment was only 0.7 year.

c Reported only 0.6 of a full-year energy savings because increment was only 0.6 year. 
TABLE 8.11 Energy Savings from Less-Frequently-Required Bridge Maintenance, $+15 \%$ Increase $\left(\mathbf{1 0}^{12} \mathrm{Btu}\right)$

\begin{tabular}{|c|c|c|c|c|c|c|}
\hline \multirow[b]{2}{*}{ Year $^{\mathrm{a}}$} & \multicolumn{3}{|c|}{$\begin{array}{l}\text { 15\% Minor Rehabilitation } \\
(+1 \text { year })\end{array}$} & \multicolumn{3}{|c|}{$\begin{array}{c}15 \% \text { Major Rehabilitation } \\
(+2.3 \text { years }) \\
\end{array}$} \\
\hline & Rural & Urban & Total & Rural & Urban & Total \\
\hline $1(8)$ & 0.06 & 0.05 & 0.11 & - & - & - \\
\hline $2(9)$ & - & - & - & - & - & - \\
\hline $3(10)$ & - & - & - & - & - & - \\
\hline $4(11)$ & - & - & - & - & - & - \\
\hline . & . & . & . & . & . & . \\
\hline . & . & . & . & . & . & . \\
\hline . & . & . & . & . & . & . \\
\hline $15(22)$ & 0.06 & 0.05 & 0.11 & 1.05 & 1.12 & 2.17 \\
\hline $16(23)$ & - & - & - & 1.05 & 1.12 & 2.17 \\
\hline $17(24)$ & - & - & - & 0.32 & 0.34 & $0.98^{\mathrm{b}}$ \\
\hline $18(25)$ & - & - & - & - & - & - \\
\hline . & . & . & . & . & . & . \\
\hline$\therefore$ & $\therefore$ & $\therefore$ & $\therefore$ & $\therefore$ & $\therefore$ & $\therefore$ \\
\hline $\begin{array}{l}\text { Average annual } \\
\text { energy savings }\end{array}$ & \multicolumn{3}{|c|}{0.169 (rural) } & (urban) & \multicolumn{2}{|c|}{0.348 (total) } \\
\hline
\end{tabular}

a Year outside parentheses is year when first energy savings begin; year within parentheses is the actual year since minor or major rehabilitation.

b Reported only 0.3 of a full-year energy savings because increment was only 0.3 year. 


\subsection{SCENARIO 6: REDUCED VOLUME OF ROAD MATERIALS REQUIRED}

What average annual U.S. energy savings will result if stronger, longer-lasting roads, using smaller volumes of materials, are developed?

Assumptions:

1. The decreased volumes of required materials have impacts in all seven types of improvements identified in Table 3.3.

2. Increments of $5 \%, 10 \%$, and $15 \%$ are assumed.

The associated energy savings are presented in Table 8.12; volume reductions are considered to be primarily "crushed-rock base" reductions. Table 8.13 summarizes annual energy savings associated with reduced roadway-material requirements. 
TABLE 8.12 Energy Savings for RoadwayMaterials Reduction $\left(10^{6} \mathrm{Btu} /\right.$ /ane-mi)

\begin{tabular}{|c|c|c|c|}
\hline \multirow[b]{2}{*}{ Roadway Improvement } & \multicolumn{3}{|c|}{$\begin{array}{c}\text { Percent Crushed-Rock } \\
\text { Base Saved }^{\text {a }}\end{array}$} \\
\hline & $5 \%$ & $10 \%$ & $15 \%$ \\
\hline 1. New construction & 28.6 & 57.1 & 85.7 \\
\hline 2. Relocation & 28.6 & 57.1 & 85.7 \\
\hline 3. Reconstruction & 28.6 & 57.1 & 85.7 \\
\hline $\begin{array}{l}\text { 4. Restoration and } \\
\text { rehabilitation }{ }^{b}\end{array}$ & 0.025 & 0.05 & 0.075 \\
\hline 5. Resurfacing ${ }^{b}$ & 0.025 & 0.05 & 0.075 \\
\hline 6. Major widening ${ }^{c}$ & 28.6 & 57.1 & 85.7 \\
\hline 7. Minor widening & 14.3 & 28.6 & 42.9 \\
\hline
\end{tabular}

a Assumed median value of $227,000 \mathrm{Btu} / \mathrm{ton}$ for crushed-rock base.

b Volume reduction applicable only to assumed addition of 2-in. overlay, which will have less crushed rock.

c A major widening equates to adding a lane and is comparable to improvements 1-3. 
TABLE 8.13 Annual Energy Savings Associated with Reductions in Roadway Materials $\left(10^{9} \mathrm{Btu}\right)$

\begin{tabular}{|c|c|c|c|c|c|c|c|c|c|}
\hline \multirow[b]{2}{*}{ Roadway Improvement } & \multicolumn{3}{|c|}{$5 \%$} & \multicolumn{3}{|c|}{$10 \%$} & \multicolumn{3}{|c|}{$15 \%$} \\
\hline & Rural & Urban & Total & Rural & Urban & Total & Rural & Urban & Total \\
\hline 1. New Construction & 5.85 & 5.75 & 11.60 & 11.68 & 11.48 & 23.16 & 17.53 & 17.23 & 34.76 \\
\hline 2. Relocation & 3.87 & 1.18 & 5.05 & 7.54 & 2.36 & 9.90 & 11.31 & 3.55 & 14.86 \\
\hline 3. Reconstruction & 55.86 & 20.78 & 76.64 & 111.53 & 41.49 & 153.02 & 167.39 & 62.27 & 229.66 \\
\hline $\begin{array}{l}\text { 4. } \begin{array}{l}\text { Restoration and } \\
\text { rehabilitation }\end{array}\end{array}$ & 0.04 & 0.01 & 0.05 & 0.08 & 0.02 & 0.10 & 0.12 & 0.04 & 0.16 \\
\hline 5. Resurfacing & 0.11 & 0.02 & 0.13 & 0.21 & 0.05 & 0.26 & 0.32 & 0.07 & 0.39 \\
\hline 6. Major widening & 8.70 & 7.73 & 16.43 & 17.38 & 15.43 & 32.81 & 26.08 & 23.16 & 49.24 \\
\hline 7. Minor widening & 10.01 & 1.96 & 11.97 & 20.02 & 3.92 & 23.94 & 30.03 & 5.88 & 35.91 \\
\hline \multicolumn{10}{|l|}{ Total } \\
\hline Rural & 84.44 & - & - & 168.44 & - & - & 252.78 & - & - \\
\hline Urban & - & 37.43 & - & - & 74.75 & - & - & 112.2 & - \\
\hline Total & - & - & 121.87 & - & - & 243.19 & - & - & 364.98 \\
\hline
\end{tabular}




\subsection{SCENARIO 7: STRONGER, SMALLER BRIDGES ARE DEVELOPED}

What average annual U.S. energy savings will result if stronger, smaller bridges, requiring less steel and concrete, become the standard for bridge design?

Assumptions:

1. Earlier calculations assumed approximately 400 tons of concrete and 65 tons of steel per 20 -ft span. These values would be equivalent to 800 tons of concrete and 130 tons of steel per typical bridge for the $40-\mathrm{ft}$ bridges used in later calculations.

2. Increments of $5 \%, 10 \%$, and $15 \%$ use 800 tons of concrete and 130 tons of steel per 40 -ft bridge as the basis for volume reductions and associated energy savings.

3. Weights for deck and superstructure are assumed to be (in tons):

\begin{tabular}{lcc}
\multicolumn{1}{c}{ Material } & Deck & Superstructure \\
\hline Concrete & 180 & 60 \\
Steel & 15 & 5
\end{tabular}

Table 8.14 shows the annual energy savings associated with volume reductions of 5\%,10\%, and $15 \%$ in bridge materials. The energy savings are calculated for new/replacement bridges and for major and minor rehabilitation of bridges. 
TABLE 8.14 Annual Energy Savings Associated with Reductions in Bridge Materials $\left(10^{9} \mathrm{Btu}\right)$

\begin{tabular}{|c|c|c|c|c|c|}
\hline \multirow[b]{2}{*}{ Increment } & \multicolumn{2}{|c|}{$\begin{array}{c}\text { Material } \\
\text { Reductions (tons) }\end{array}$} & \multicolumn{2}{|c|}{$\begin{array}{c}\text { Number of } \\
\text { Bridges Repaired } \\
\text { Annually } \\
\end{array}$} & \multirow{2}{*}{$\begin{array}{c}\text { Annual } \\
\text { Energy } \\
\text { Conserved }^{\mathrm{a}, \mathrm{b}} \\
\end{array}$} \\
\hline & Concrete & Steel & Rural & Urban & \\
\hline \multicolumn{6}{|l|}{$5 \%$} \\
\hline New/Replacement & 40.0 & 6.5 & 2,381 & 1,073 & 272.9 \\
\hline Major rehabilitation & 12.0 & 1.0 & 513 & 457 & 22.1 \\
\hline Minor rehabilitation & 9.0 & 0.75 & 332 & 236 & 9.6 \\
\hline Total & & & & & 304.6 \\
\hline \multicolumn{6}{|l|}{$10 \%$} \\
\hline New/Replacement & 80.0 & 13.0 & 2,381 & 1,073 & 545.9 \\
\hline Major rehabilitation & 24.0 & 2.0 & 513 & 457 & 44.2 \\
\hline Minor rehabilitation & 18.0 & 1.5 & 332 & 236 & 19.2 \\
\hline Total & & & & & 609.3 \\
\hline \multicolumn{6}{|l|}{$15 \%$} \\
\hline New/Replacement & 120.0 & 19.5 & 2,381 & 1,073 & 818.8 \\
\hline Major rehabilitation & 36.0 & 3.0 & 513 & 457 & 66.2 \\
\hline Minor rehabilitation & 27.0 & 2.3 & 332 & 236 & 28.8 \\
\hline Total & & & & & 913.8 \\
\hline
\end{tabular}

a Assumed $1.6 \times 10^{6} \mathrm{Btu} /$ ton as "in-place" constructed energy from Table 3.2 for construction of reinforced PCC.

b Concrete and steel were combined to obtain material weights that were multiplied by $1.6 \times 10^{6} \mathrm{Btu} / \mathrm{ton}$. 


\subsection{SCENARIO 8: VEHICULAR TRAFFIC CONGESTION REDUCED}

What annual energy savings will accrue from fewer roadway and bridge construction projects?

Assumptions:

1. There are $1,542,908$ paved miles of rural roads and 716,237 paved miles of urban roads in 1990, as shown in Highway Statistics (Federal Highway Administration 1990, p. 122).

2. These paved-road mileages represent $49.4 \%$ of all rural road miles and $94.6 \%$ of all urban road miles.

3. A $10-\mathrm{mi} / \mathrm{gal}$ decrease (i.e., $20 \mathrm{mi} / \mathrm{gal}$ to $10 \mathrm{mi} / \mathrm{gal}$ or inefficiency penalty in fuel economy is assumed when vehicles must slow down to inefficient (or "crawl") travel speeds because of construction congestion. This penalty represents approximately a $50 \%$ reduction in fuel economy.

4. Reduced speeds result from $75 \%$ of annual construction, as assumed from Table 3.3. Rural: $75 \% \times 9,138.9$ construction miles $=6,854.2$ miles with reduced travel speeds Urban: $75 \% \times 2,345$ construction miles $=1,758.8$ miles with reduced travel speeds.

5. A value of $6,095 \mathrm{Btu}$ per vehicle-mile is assumed (Oak Ridge National Laboratory 1992, Table 2.12).

6. An average of 116.2 days per road project is derived from Table 2.12 of Oak Ridge National Laboratory (1992).

7. Increased construction/maintenance intervals of $5 \%, 10 \%$, and $15 \%$ are equated to 1,2 , and 3 additional years, respectively, for a 20 -year highway life cycle.

Energy savings obtained by means of reduced highway congestion associated with lessfrequent construction delays are indicated in Table 8.15. 
TABLE 8.15 Energy Savings for Reduced Traffic Congestion Associated with LessFrequent Construction Delays $\left(10^{12} \mathrm{Btu}\right)$

\begin{tabular}{|c|c|c|c|c|c|}
\hline \multirow[b]{2}{*}{ Rate and Year } & \multicolumn{2}{|c|}{ Rural Energy Savings } & \multicolumn{2}{|c|}{ Urban Energy Savings } & \multirow[b]{2}{*}{$\begin{array}{c}\text { Total } \\
\text { Average } \\
\text { Annual Saving }\end{array}$} \\
\hline & $\begin{array}{c}\text { One-Time } \\
\text { Savings }\end{array}$ & $\begin{array}{c}\text { Average } \\
\text { Annual } \\
\text { Savings }\end{array}$ & $\begin{array}{c}\text { One-Time } \\
\text { Savings }\end{array}$ & $\begin{array}{l}\text { Average } \\
\text { Annual } \\
\text { Savings }\end{array}$ & \\
\hline $5 \%, 1$ year & 4.9 & 0.25 & 6.2 & 0.31 & 0.56 \\
\hline $10 \%, 2$ years & 9.8 & 0.49 & 12.4 & 0.62 & 1.11 \\
\hline $15 \%, 3$ years & 14.7 & 0.74 & 18.6 & 0.93 & 1.67 \\
\hline
\end{tabular}




\section{SUMMARY AND CONCLUSIONS}

The average annual energy savings for the eight proposed scenarios (or actions) are summarized in Table 9.1. These eight scenarios are not mutually exclusive. Decisions about one course of action may have a major impact on another scenario. For example, increases in road and bridge life cycles (Scenarios 2 and 3) and reduction of the frequency of maintenance (Scenarios 4 and 5) will definitely affect the frequency of traffic-congestion delays (Scenario 8).

Annual energy savings from highway materials improvements, on the order of $0.1 \times 10^{12}$ to $2.1 \times 10^{12} \mathrm{Btu}$, are relatively small compared to energy savings from improvements in vehicle fuel economy. For perspective, the annual energy savings as a result of an improvement in new-car fuel efficiency of $0.5 \mathrm{mi} / \mathrm{gal}$ amounts to about $10 \times 10^{12} \mathrm{Btu}$ (assuming an average vehicle on-road fuel efficiency of $22 \mathrm{mi} / \mathrm{gal}, 14,000$ vehicle miles traveled per year, and annual sales of eight million vehicles). conclusions:

The individual analyses and the summary of results in Table 9.1 support the following

- Reducing the rolling resistance of the nation's roads (Scenario 1) will produce negligible energy savings. In fact, Scenario 1 may have an overall negative impact on safety.

- Reducing bridge maintenance (Scenario 5) will produce very small energy savings.

- Constructing roads that require smaller volumes of materials (Scenario 6) will also produce very small energy savings.

- Roadway initiatives appear to produce generally higher energy savings than bridge initiatives.

- Increasing road life or extending the effective life of our nation's highways (Scenario 2) appears to be the initiative that will produce the largest energy savings.

- Efforts to reduce traffic congestion, particularly in locations where traffic volumes are high, will produce major energy savings compared to the other scenarios. The assumptions used in the calculations for Scenario 8 appear reasonable, but the variability of assumptions regarding traffic volumes, 
TABLE 9.1 Summary of Average Annual Energy Savings by Scenario

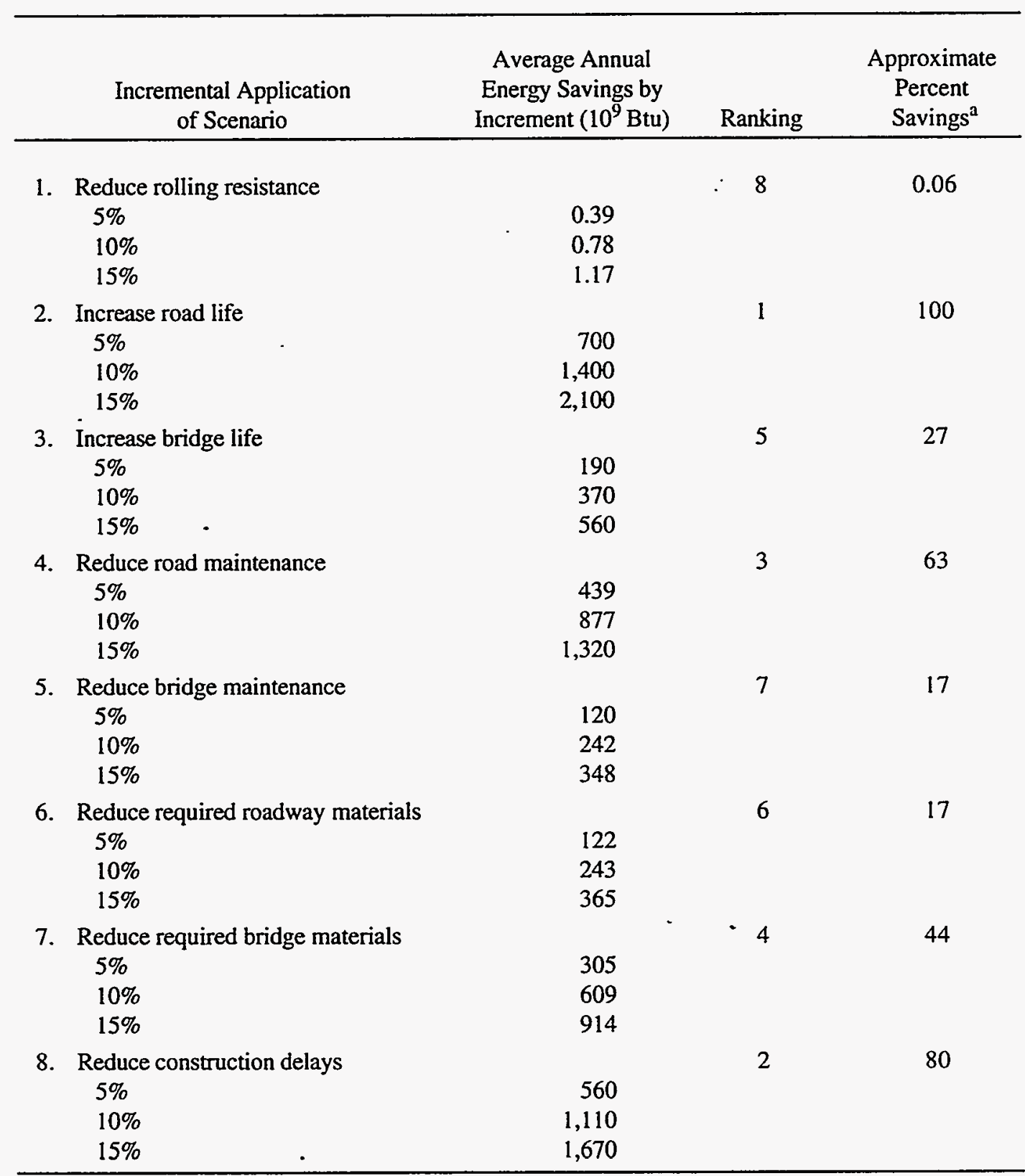

a Percent savings relative to the best scenario, No. 2 (increasing road life). 
durations of construction, and nature of delays (such as long waits vs. mere speed decreases) plays a major role in determining final energy savings. This wide range of variability associated with differing assumptions must be recognized. Depending upon the various assumptions, Scenario 8 could easily have been ranked first through seventh in the ranking scheme shown in Table 9.1.

- Energy savings as a result of highway infrastructure improvements are small relative to energy savings resulting from vehicle fuel efficiency improvements.

- Other potential benefits of advanced materials for highway infrastructure, for example, improved productivity in the transportation sector, may be much more significant than energy benefits. These impacts were not addressed in this study. 


\section{REFERENCES}

Bureau of the Census, 1991, Statistical Abstracts of the U.S.: 1991, 111th Edition, U.S. Department of Commerce, Washington, D.C.

Charles River Associates, Inc., 1989, The Evolution of the U.S. Iron and Steel Industry and the Implications for Natural Gas.

Energy Information Administration, 1994, Annual Energy Outlook for 1994 with Projections to 2010, DOE/EIA-0383(94), Washington, D.C.

Epps, J.A., and Finn, F.N., 1980, "Requirements Associated with Pavement Construction, Rehabilitation, and Maintenance," Energy, Economy, and Energy Considerations in Design Construction and Materials, in Texas Transportation Institute Research Report 214-19, Texas A\&M University System, College Station, Texas.

Federal Highway Administration, 1990, "Public Road and Street Mileage - 1990," Highway Statistics, 1990, Washington, D.C.

Garber, N.J., and L.A. Hoel, 1988, Traffic and Highway Engineering, West Publishing Co., St. Paul, Minn.

Limpert, R., 1978, Motor Vehicle Accident Reconstruction and Cause Analysis, The Michie Co., Charlottesville, Va.

National Research Council, 1992, Focus, Strategic Highway Research Program, Washington, D.C.

Oak Ridge National Laboratory, 1992, Transportation Energy Data Book: Edition 12, Report ORNL-6710, Oak Ridge, Tenn.

Secretary of Transportation, 1989, The Status of the Nation's Highways and Bridges: Conditions and Performance and Highway Bridge Replacement and Rehabilitation Program 1989, Report of the Secretary of Transportation to the United States Congress, U.S. Government Printing Office, Washington, D.C.

Yoder, E.J., and M.W. Witczak, 1975, Pavement Design, John Wiley and Sons, New York, N.Y. 
APPENDIX:

DEFINITIONS OF INDUSTRY TERMS 


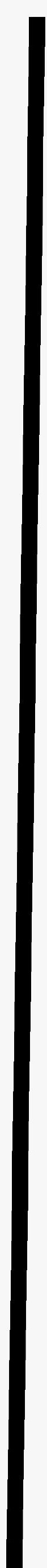




\section{APPENDIX: \\ DEFINITIONS OF INDUSTRY TERMS}

The following simplified definitions may prove helpful:

Aggregates. Mineral particles that have rock as their origin (e.g., sand, gravel, fieldstone, and crushed rock).

Arterial. A higher-service highway that typically serves a line-haul function. "Major" and "minor" are merely modifiers that suggest service volumes and overall role or function.

Asphalt Cement Concrete ( $A C C$ ). A concrete formed by the hardening of a mixture of bitumens in asphalt cement and aggregates.

Bitumens. A mixture of hydrocarbons and other substances that occurs naturally or by distillation of coal or petroleum and serves as the binder in ACC.

Bridge. A structure that spans an obstacle, such as a waterway, railroad, or another roadway. Such modifiers as "concrete" or "steel" indicate a bridge's dominant component.

Cement. A construction binder or adhesive that is mixed with aggregate and water to form a hardened mass.

Collector. An urban or rural road that collects vehicular traffic from local roads and streets and connects with or feeds arterial highways and freeways.

Concrete. A generic description of any of a number of construction materials. It is often used as a shortened term for Portland cement concrete. Concrete can contain asphalt or Portland cement. Construction "concrete" consists of a conglomerate of sand, gravel, pebbles, broken stone, or slag in a mortar or cement matrix.

Freeway. High-use highway serving large traffic volumes, typically with multiple lanes and limited access.

Gradation. Distribution of sizes in a given sample of crushed rock (very important in pavement design). 
Infrastructure. The basic facilities, equipment, and installations needed for the functioning of a system or organization. In this study, the term "highway infrastructure" is primarily interpreted in terms of roads and bridges.

Major Bridge Components. Major bridge components are typically defined as the deck, the superstructure, and the substructure. The conditions of these components are important to the identification of deficiencies and the assessment of improvements.

Portland Cement Concrete (PCC). A concrete formed by the curing of Portland cement, aggregates, and water. Portland cement is a hydraulic cement formed by heating a mixture of limestone and clay and pulverizing the resultant clinker.

Road. A constructed travelway or roadway on which motorized vehicles travel. This rather generic term could include a street, collector road, major or minor arterial, or a freeway.

Rural. Area with population less than 5,000.

Small Urban (Suburban). Area with population of 5,000-50,000.

Street. A low-volume local, urban road or a local road in a residential subdivision or a commercial or industrial development.

Urban. Area with a population greater than 50,000 . 